British Standards Institution and other bodies ; and further restrictive legislation in various directions would appear to be not unlikely. The problem of the measurement of noise, or rather of its 'equivalent loudness', is finding generally accepted solution both in Great Britain and abroad. The standard of comparison is a reference tone of 1,000 cycles per second with a specified arbitrary 'zero' of intensity. If the reference tone is increased in successive decibel steps of energy above the zero, the resulting changes of loudness are expressed in numerically identical steps on a scale of phons. The equivalent loudnesses of other sounds and noises are evaluated by aural matching against the reference tone when suitably adjusted. Other features to which Dr. Hughes refers in his informative article are the abatement of both air-borne sounds and impact noises and vibrations in buildings, impulse noises, and commercially available noise-measuring instruments.

\section{Wonders of Tinplate}

AN interesting film dealing with tinplate and canning, produced in France under the title "Magie du Fer-Blanc", was shown for the first time in England on December 2 at the Polytechnic Extension, Little Tichfield Street, London, W.1. The display took place under the auspices of the International Tin Research and Development Council, and Sir John Campbell, chairman of the Internation Tin Committee, introduced to the audience M. Peissi, director of l'Office Technique pour l'Utilisation de l'Acier, by whom the film had been produced. Various phases in the production of tinplate, the fabrication of containers and the canning of food were depicted. At present the film has French subtitles, but we understand that it is probable that an English accompaniment will be arranged and the film exhibited publicly in Great Britain.

\section{Meat Inspection in South America}

THE fourteenth Benjamin Ward Richardson lecture, founded in 1922 by the Model Abattoir Society (dissolved in 1935), was delivered in the rooms of the Royal Sanitary Institute, which has taken over the management of the Richardson Trust, on November 12, by Dr. M. T. Morgan of the Ministry of Health, on the system of health inspection of meat and meat products destined for export in the great abattoirs of South America. In accordance with instructions from his Department, Dr. Morgan recently visited the large factory abattoirs in the Argentine, Uruguay and Brazil which serve for the preparation of meat and meat products destined for export overseas and for local consumption. The products range from the finest quality chilled beef destined for the English market down to every variety of by-product from agricultural fertilisers to buttons for clothes. The finest quality meat is produced in the Argentine, and a slightly inferior quality in Uruguay. The system of inspection of meat and meat products is the same in all three countries, but is most highly developed in the Argentine, where it is a special branch of the State service of inspection of livestock and is not attached to the public health service as in Great Britain. A most efficiont inspoction of the animals is mude both before and after death. Wholo carcasses or sides or portions or viscera aro rejected on the slightest grounds of a suspicion that they are unhealthy or unsuitable for human consumption. In conclusion, Dr. Morgan states that in all three countries he was struck by the extraordinarily high standard of the service of inspection and the extreme cleanliness and efficiency in every department of the enormous factories.

\section{Britain in the Dark Ages}

A MAP of Britain in the Dark Ages (A.D. 410 to 871 ) is the third of the period maps to be published by the Ordnance Survey. The south sheet covering England, Wales and part of southern Scotland has now appeared (Southampton: Ordnance Survey. Cloth mounted. 5s. Paper, flat and unmounted. 2s. 6d.). The scale is $1: 1,000,000$ and the map is contoured and layer coloured. No attempt has been made at the almost impossible task of restoring the ancient coast line, but the forest covering is shown, and is the same as that on the map of Roman Britain. The entries on the map have been derived from both archæological and historical sources, and an attempt has been made to represent both the Celtic and Saxon aspects of the period. Different characters are used for place names of the two origins. Latin names, constantly used in documents of the period, are also differentiated. Roman roads, with one exception are omitted, since their use was uncertain. Churches, crosses, battle-sites, villages and other dwellings, and burial places are shown, and in the introductory pamphlet that goes with the map there are small maps showing respectively place names ending in -ing and the distribution of cemeteries. There is a complete index of ancient names with modern equivalents. The map is a beautiful example of cartography and shows a wide range of historical research without any suggestion of crowding of names or symbols.

\section{The Present Age}

WE have received the first two numbers of the Present Age, a new monthly journal edited and published by Dr. W. J. Stein, 144 Harborough Road, London, S.W.16 (2s, a month). The editor, in a covering circular, points out that modern life has created such a high degree of specialisation that it has become almost impossible to have cognisance of more than one sphere of knowledge or activity. The Present Age is designed to relate different fields of knowledge by the publication of articles apparently independent, but showing their true interrelationships. The January issue (1, No. 2) contains, among others, historical articles on "King Arthur", "Christmas through the Ages", and "Eurythmy in Ancient Greece", the last-named with four excellent plates of Nereids from figures in the Nereid Room of the British Museum. Science is represented by articles on "Alterations in the Earth's Surface", and "The 
Classification of the Animal Kingdom", and medical science by one on "The Nature and Treatment of Sclerosis", a process terminating in hardening and calcification in tissues and organs. The latter presents the subject largely from a metaphysical and homøopathic point of view, and cannot be accepted as representing modern medical conceptions. The metaphysical also looms large in "Alterations in the Earth's Surface", and so far as science is concerned, the articles can scarcely be accepted as representative of its modern aspects.

\section{New Garden Plants}

THE present generation of horticulturists is fortunate in the ever-increasing number of new contributions to garden beauty. Scientific hybridisation and selection have produced more pleasing shades of bloom, or enhanced symmetry of form from old favourites, whilst ardent botanists roam amongst the wilder parts of the world to find new grandeur for the rockery or herbaceous border. Plants from these sources which have stood the test of English cultivation are described ( $J$. Roy. Hort. Soc., November) by Dr. Fred Stoker, who writes on "Ericaceous Plants" and Mr. Ben Wells, who discusses herbaceous subjects. Both accounts are well illustrated with excellent half-tone plates, and give many practical details.

\section{Memorandum on Pneumonia}

PNEUMONTA, as a cause of national mortality, has long been a matter of concern to public health authorities. In 1934, for example, this disease was responsible for 28,623 deaths in England and Wales, and in times of influenza prevalence the martality may reach a much higher figure. The Ministry of Health has, therefore, issued a Memorandum (Memo. 189 Med.) with covering circular (No. 1499) on the subject for the use of public health authorities, in which the classification and bacteriology, its prophylaxis and the general administrative measures applicable, are dealt with (H.M. Stationery Office. ld. net).

\section{Physical Society's Exhibition}

THE twenty-sixth annual exhibition of scientific instruments and apparatus arranged by the Physical Society opens at the Imperial College of Science and Technology on January 7. The times of admission are 3-6 and 7-10 p.m. (January 7), 2-4, 4-6 and 7-10 p.m. (January 8) and 3-6 and 7-10 p.m. (January 9). A descriptive catalogue of the exhibits can be obtained from the Exhibition Secretary, Physical Society, I Lowther Gardens, Exhibition Road, London, S.W.7 (1s. post paid), to whom applications for tickets of admission should also be addressed.

\section{Indian Science Congress Association}

THE twenty-third annual meeting of the Indian Science Congress Association is being held on January 2-8 at Indore, under the presidency of Rai Sir Upendranath Brahmachari Bahadur. The presidents of sections are as follow: (1) Mathematics and Physics: Dr. T. Royds, director of the Kodaikanal Observatory ; (2) Chemistry: Dr. P. C. Guha, professor of organie chemistry, Indian Institute of Science, Bangalore; (3) Geology and Geography: B. Rama Rao, officiating director of geology, Mysore Geological Department, Bangalore ; (4) Botany: Dr. S. R. Bose, professor of botany, Carmichael Medical College, Calcutta ; (5) Zoology: Dr. H. K. Mookerjee, University professor and head of the Department of Zoology, University of Calcutta ; (6) Anthropology: H. C. Chakladar, lecturer in anthropology, University of Calcutta; (7) Agriculture: A. K. Yagna Narayan Aiyer, formerly director of agriculture, Sankarapuram, Bangalore ; (8) Medical and Veterinary Research: Lieut.-Col. H. E. Shortt, director of the King Institute, Guindy, Madras; (9) Physiology: Dr. W. Burridge, professor of physiology, University of Lucknow ; (10) Psychology : J. M. Sen, inspector of schools, Presidency Division, Bengal.

\section{Recent Meteors and Fireballs}

The Meteoric Display of November 21. A letter has been received from Mohd. A. R. Khan, whose wireless message was published in NATURE of November 30, p. 867, as follows: "I observed over one hundred meteors between $6 \mathrm{~h} .50 \mathrm{~m}$. and $7 \mathrm{~h} .10 \mathrm{~m}$. G.M.T. on November 21, of which several were of first magnitude with long trails. Eleven more were observed in the next 20 minutes. The sky was rather hazy. Perhaps the richest part of the shower occurred somewhat earlier, before I began observation". The possible return of this shower should be looked for by meteor observers in future yoars.

A great Detonating Fireball. On November 25, at $0 \mathrm{~h} .20 \mathrm{~m}$. U.T., a meteor which announced its arrival with a 'blinding glare of light' was observed in south-west England by many people. At Bridgwater there was a loud explosion after the disappear. ance of the fireball, "followed by a rumbling noise resembling thunder, lasting for about a minute". Heavy detonations were also heard at Weston-super. Mare and Bristol. Mr. A. King, of 53 Victoria Road, Ashby, Scunthorpe, Lincs, has received some ten accounts, but they are mostly so vague (and in some cases contradictory) that a definitive real path cannot be computed. All that can be said in this respect is that the object passed over the district between Bridgwater and Bristol at a low height.

Daylight Firebali. On December 3, at 1lh. 30m. U.T., an observer in Bradford saw a meteor with a long tail shoot across the eastern sky. This must have been a very fine fireball. Observations of the fireball should be sent to Mr. King.

\section{Announcements}

THe Catherine Wolfe Bruce Gold Medal for 1936 of the Astronomical Society of the Pacific has been awarded to Prof. A. O. Leuschner, professor of astronomy and director of the Students' Observatory in the University of California, for distinguished services in astronomy. Prof. Leuschner is an authority on the determination of the orbits of planets. 